\title{
2. Mg-Fe PARTITIONING BETWEEN PLAGIOCLASE AND LIQUID IN BASALTS OF HOLE 504B, ODP LEG 111: A STUDY OF MELTING AT 1 ATM1
}

\author{
Hiroaki Sato ${ }^{2}$
}

\begin{abstract}
The effect of oxygen fugacity $\left(\mathrm{f}_{2}\right)$ on the partition relationship of $\mathrm{Mg}$ and Fe between plagioclase and sillicate liquid was investigated at $1 \mathrm{~atm}$ for basaltic samples recovered during ODP Leg 111 from Hole 504B. Samples 111-504B143R-2 (Piece 8) and 111-504B-169R-1 (Piece 1) have plagioclase as the liquidus phase. The distribution coefficient of $\mathrm{Mg}$ between plagioclase and melt is constant at about 0.04 against the variation of $\mathrm{f}_{2}$, whereas that of $\mathrm{Fe}$ (total $\mathrm{Fe}$ ) varies from 0.3 at $\mathrm{f}_{2}=0.2 \mathrm{~atm}$ to 0.03 at $\mathrm{f}_{2}=10^{-11.5}$ at $1200^{\circ} \mathrm{C}$. The distribution coefficient of $\mathrm{Mg}$ is slightly higher than that calculated from the phenocryst and bulk-rock compositions, suggesting a kinetic disequilibrium effect on the distribution of $\mathrm{Mg}$ in plagioclase. Because $\mathrm{Mg}, \mathrm{Fe}$, and $\mathrm{Fe}^{3+}$ have similar diffusion coefficients in silicate melt, the disequilibrium effect is greatly reduced for the exchange reaction of $\mathrm{Mg}$ and total $\mathrm{Fe}$ between plagioclase and liquid. The exchange partition coefficient is highly dependent on $\mathrm{f}_{2}$, with $\log \mathrm{f}_{2}$ ranging from -0.7 to -11.5 at approximately $1200^{\circ} \mathrm{C}$. Using this relationship, the $\mathrm{f}_{2}$ of crystallization of the magmas is estimated to be near the one defined by the fayalite-quartz-magnetite assemblage.
\end{abstract}

\section{INTRODUCTION}

$\mathrm{Mg}$ and $\mathrm{Fe}$ are important minor constituents of plagioclase in oceanic ridge basalts. Bryan (1974) described the sector-zoned distribution of $\mathrm{Mg}$ and $\mathrm{Fe}$ in some ocean-floor basalts, with $\mathrm{Mg}$ and $\mathrm{Fe}$ occupying the tetrahedral site of plagioclase. In examining $\mathrm{Fe}$ and $\mathrm{Mg}$ accommodation in plagioclase, Longhi et al. (1976) observed variable distribution coefficients of Fe between plagioclase and liquid among lunar and terrestrial basalts, which they ascribed to the effect of oxygen fugacity $\left(\mathrm{f}_{2}\right)$. Drake and Weill (1975) reported that $f_{\mathrm{O}_{2}}$ affects the distribution coefficient of europium between plagioclase and liquid; divalent and trivalent europium have different distribution coefficients, and hence the distribution coefficient of total Eu could depend on the $\mathrm{f}_{\mathrm{O}_{2}}$ of the crystallizing magmas. Similarly, ferric and ferrous iron may have different partition coefficients, and the partition coefficient of total $\mathrm{Fe}$ can be used as an indicator of the redox states of magmas.

In this study, the author conducted melting experiments at 1 atm on two basalt samples recovered from Hole 504B during Ocean Drilling Program (ODP) Leg 111 to determine if the $\mathrm{Mg}$ Fe partitioning between plagioclase and silicate liquids can be used to estimate the $\mathrm{f}_{\mathrm{O}_{2}}$ of the magmas. Problems concerning the formulation of the exchange partition coefficient of $\mathrm{Mg}$ and Fe between plagioclase and magma are also discussed in this paper.

\section{Hole 504B Basalt Samples}

Two samples of relatively fresh basalts were analyzed in this study. Bulk-rock chemical and modal compositions of the samples are listed in Table 1.

Sample 111-504B-143R-2 (Piece 8) is a sparsely phyric olivine-plagioclase basalt with \#Mg $(=100 \times \mathrm{Mg} /[\mathrm{Mg}+\mathrm{Fe}])$ of 65 . Olivine phenocrysts are completely altered to clay minerals and can be identified only by their pseudomorphic forms. The pseudomorphs are euhedral, ranging from 0.1 to $1 \mathrm{~mm}$ in diameter. Rare chromian spinel octahedra are included in the pseudo-

\footnotetext{
${ }^{1}$ Becker, K., Sakai, H., et al., 1989 Proc. ODP, Sci. Results, 111: College Station, TX (Ocean Drilling Program).

2 Faculty of Integrated Arts and Sciences, Hiroshima University, Hiroshima, 730, Japan.
}

morphs. Plagioclase phenocrysts are also euhedral and tabular and are $0.1-1.5 \mathrm{~mm}$ across. Plagioclase phenocrysts commonly show steplike normal zoning at the rim. The compositions of the cores of plagioclase phenocrysts are $\mathrm{An}_{80-88}$, whereas compositions of the margin and groundmass plagioclase are $\mathrm{An}_{45-80}$. $\mathrm{MgO}$ contents of the cores of the plagioclase phenocrysts are uniformly about $0.2-0.3 \mathrm{wt} \%$, whereas $\mathrm{Mg}$ contents of the rim and groundmass plagioclase attain maximum values of $0.3-0.4$ wt $\%$ at $A n_{70-75}$, from which they decrease as the An content decreases (Fig. 1).

$\mathrm{FeO}$ (total $\mathrm{Fe}$ ) concentrations of the cores of the plagioclase phenocrysts in Sample 111-504B-143R-2 (Piece 8) are about 0.4 $\mathrm{wt} \%$. The $\mathrm{FeO}$ concentration of plagioclase increases monotonously vs. decreases in the An component to about $1.0 \mathrm{wt} \%$ at $\mathrm{An}_{50-60}$ (Fig. 1). The groundmass constituents are plagioclase, augite, titanomagnetite, and interstitial clay minerals, which may be the alteration product of mesostasis. The groundmass has a subophitic texture and is almost holocrystalline.

Sample 111-504B-169R-1 (Piece 1) is a sparsely phyric olivine-augite-plagioclase basalt. Olivine is completely altered to clay minerals, comprising about $1 \%$ of the rock volume. The euhedral olivine pseudomorphs are $0.1-1 \mathrm{~mm}$ in diameter. The fresh augite phenocrysts show idiomorphic short-prismatic forms, are $0.2-2 \mathrm{~mm}$ in length, and comprise about $2 \%$ of the modal content. Augite compositions are subcalcic augite, with $\mathrm{Cr}_{2} \mathrm{O}_{3}$ contents of $0.5 \mathrm{wt} \%$ in the magnesian cores. Plagioclase phenocrysts, which form $1.4 \%$ of the rock volume, are euhedral, tabular, and 0.2-1 mm long. The An contents of the cores of the plagioclase phenocrysts range from 80 to 90 . MgO contents are $0.2-0.3 \mathrm{wt} \%$ for the cores of plagioclase phenocrysts, whereas $\mathrm{FeO}$ (total $\mathrm{Fe}$ as $\mathrm{FeO}$ ) contents increase from 0.4 to $1 \mathrm{wt} \%$ as the An contents of the plagioclase decrease.

\section{EXPERIMENTAL METHODS}

The wire-loop method (Presnall and Brenner, 1974; Donaldson et al., 1975) was used for the phase equilibrium and element partitioning experiments in this study. All runs were made at 1-atm pressure in a vertical quench furnace of Siliconit with $\mathrm{SiC}$ heating elements at the Faculty of Integrated Arts and Sciences Building, Hiroshima University. The $\mathrm{f}_{2}$ was controlled by mixing $\mathrm{CO}_{2}$ and $\mathrm{H}_{2}$ gases, with the mixing ratio determined by the thermodynamic calculation performed by Dr. A. Tsuchiyama after the method of Nafziger et al. (1971). The $\mathrm{f}_{2}$ of the furnace was calibrated against the reaction $\mathrm{Ni}+0.5 \mathrm{O}_{2}=\mathrm{NiO}$ at the 
Table 1. ODP Leg 111 basalt samples from Hole 504B.

\begin{tabular}{|c|c|c|c|c|c|c|c|}
\hline \multirow{2}{*}{$\begin{array}{l}\text { Sample } \\
\text { Phase } \\
\text { Volume }\end{array}$} & \multicolumn{3}{|c|}{ 143R-2 (Piece 8) } & \multicolumn{4}{|c|}{ 169R-1 (Piece 1) } \\
\hline & ${ }^{\mathrm{a} B u l k}$ & $\begin{array}{c}\text { Plagioclase } \\
\text { phenocryst } \\
4.7\end{array}$ & $\begin{array}{c}\text { Olivine } \\
\text { phenocryst } \\
0.7\end{array}$ & ${ }^{\mathrm{b}}$ Bulk & $\begin{array}{c}\text { Plagioclase } \\
\text { phenocryst } \\
1.4\end{array}$ & $\begin{array}{c}\text { Clinopyroxene } \\
\text { phenocryst } \\
1.8\end{array}$ & $\begin{array}{c}\text { Olivine } \\
\text { phenocryst } \\
1.1\end{array}$ \\
\hline $\begin{array}{l}\text { Averaged } \\
\text { analyses }\end{array}$ & 6 & 18 & Altered & 4 & 7 & 1 & Altered \\
\hline $\mathrm{SiO}_{2}$ & $49.21(25)$ & $46.98(50)$ & & $49.88(28)$ & $46.77(58)$ & 53.06 & \\
\hline $\mathrm{TiO}_{2}$ & $0.84(21)$ & $0.02(01)$ & & $1.10(05)$ & $0.01(01)$ & 0.25 & \\
\hline $\mathrm{Al}_{2} \mathrm{O}_{3}$ & $15.91(12)$ & $33.19(38)$ & & $14.88(15)$ & $33.58(51)$ & 2.69 & \\
\hline $\mathrm{FeO}$ & $8.50(10)$ & $0.38(05)$ & & $9.40(39)$ & $0.43(04)$ & 4.89 & \\
\hline $\mathrm{MnO}$ & $0.11(02)$ & $0.05(02)$ & & $0.15(05)$ & $0.01(02)$ & 0.14 & \\
\hline $\mathrm{MgO}$ & $8.96(06)$ & $0.23(03)$ & & $8.42(14)$ & $0.23(02)$ & 18.53 & \\
\hline $\mathrm{CaO}$ & $12.90(19)$ & $17.59(39)$ & & $13.14(15)$ & $17.68(26)$ & 20.38 & \\
\hline $\mathrm{Na}_{2} \mathrm{O}$ & $1.88(03)$ & 1.80 (19) & & $1.95(04)$ & $1.63(24)$ & 0.18 & \\
\hline $\mathrm{K}_{2} \mathrm{O}$ & $0.01(01)$ & $0.00(00)$ & & $0.01(01)$ & $0.01(01)$ & 0.01 & \\
\hline $\mathrm{Cr}_{2} \mathrm{O}_{3}$ & & & & & & 0.60 & \\
\hline & 98.32 & 100.24 & & 98.93 & 100.35 & 100.73 & \\
\hline
\end{tabular}

Note: Numbers in parentheses denote one standard deviation in terms of least units cited.

${ }^{a}$ Electronprobe microanalyses of glass (run $43 \mathrm{~A}$, Table 2).

b Electronprobe microanalyses of glass (run $44 \mathrm{~B}$, Table 2 ).

sample sites. Across the temperature range of $1150^{\circ}-1260^{\circ} \mathrm{C}, \mathrm{fO}_{2}$ was accurate to within $0.5 \mathrm{log}$ units. The temperature was measured with Pt$\mathrm{Pt} / 13 \mathrm{Rh}$ thermocouples calibrated against the melting point of gold and diopside at the sample sites. The temperature measurements are accurate to within $5^{\circ} \mathrm{C}$

Two types of melting schedules were used (Fig. 2). The equilibrium liquidus temperature of plagioclase was determined with the fusion (or heating) experiment (Gibb, 1974), in which the temperature is raised to a fixed value without overshooting and then maintained for a certain period before quenching the charges in distilled water. Because of the lack of fresh olivine crystals in the starting materials, the temperature of olivine appearance could not be determined.

The growth (or cooling) experiment was used to nucleate and grow crystals from completely molten liquids. Initially, the charge temperature is raised to $1300^{\circ} \mathrm{C}$ for $1 \mathrm{hr}$, and then dropped to a fixed temperature within $10 \mathrm{~min}$ without undershooting. The temperature is maintained for a certain period, after which the charges are dropped into distilled water by electrically cutting the platinum wire hanging the wire loop.

Because supercooling effects are inevitable in the growth of crystals in basaltic melts (Gibb, 1974; Donaldson, 1979; Baker and Grove, 1985), seeded runs were made with fusion time schedules to grow plagioclase at a small degree of undercooling $\left(\Delta \mathrm{T}=15^{\circ}-25^{\circ} \mathrm{C}\right)$ for $43-46 \mathrm{hr}$. The initial pellets consisted of fused glass powder and plagioclase seed crystals; however, the plagioclase growth rate was too low to produce overgrowth on the seeded plagioclase for electronprobe microanalyses. Reversed experiments would be difficult to achieve in runs of reasonable duration because of the slow diffusion rates of ferric and ferrous irons and magnesium in plagioclase, as noted in the seeded experiments. Only the growth experiments were used to determine element partition coefficients.

\section{RESULTS}

The experimental results are presented in Table 2 and Figure 3 . The plagioclase liquidus temperatures were determined by the heating experiment. Sample 111-504B-143R-2 (Piece 8) yielded a liquidus temperature of $1253^{\circ} \pm 3^{\circ} \mathrm{C}$, whereas Sample 111504B-169R-1 (Piece 1) yielded $1235^{\circ} \pm 5^{\circ} \mathrm{C}$. The cooling experiments showed the marked delay of plagioclase nucleation demonstrated by Gibb (1974) and Tsuchiyama (1983). Undercooling by about $30^{\circ} \mathrm{C}$ yielded nucleation and growth of plagioclase (Fig. 3).

Electron microprobe analyses of the phases in the experimental charge are shown in Table 3 . Glasses are chemically homogeneous, but plagioclase crystals may be slightly zoned (Fig. 4). Therefore, only the rim compositions of the plagioclases were used in this work. Although Longhi et al. (1976) suggested considerable effects of secondary fluorescence in analyzing iron in plagioclase rims, the iron contents of the plagioclase cores and rims within a charge are within the analytical errors (Fig. 4). Some of the runs conducted at reduced conditions show iron loss from the glass (e.g., run 41A) as a result of the use of undoped 0.1-mm-diameter platinum wire. The errors induced by this effect are mostly within the analytical errors of the partition coefficients.

The An contents of the plagioclases are well correlated to the $\mathrm{CaO} / \mathrm{Na}_{2} \mathrm{O}$ ratio and/or the normative $\mathrm{An} /(\mathrm{An}+\mathrm{Ab})$ ratio of the coexisting glass. The most calcic plagioclase obtained in these experiments has an An content of about 84 (run 15A; Table 3). As one of the most calcic compositions reported in experimental products of ocean-floor basalts (Fukuyama and Hamuro, 1978; Walker et al., 1979; Grove and Bryan, 1983; Tormey et al., 1987), these data reflect the highly depleted chemical characteristics of the Hole 504B basalts (Autio and Rhodes, 1982; Natland et al., 1982). The calcic plagioclase coexisted with glass that has $\mathrm{a} \mathrm{CaO} / \mathrm{Na}_{2} \mathrm{O}$ ratio of about 7 . Therefore, the highly calcic plagioclase phenocrysts $\left(\mathrm{An}_{85-90}\right)$ common in oceanfloor basalts possibly crystallized from a calcic melt $(\mathrm{CaO} /$ $\mathrm{Na}_{2} \mathrm{O}=7-9$ ), as suggested by Elthon and Casey (1985).

As Bryan (1974) noted, $\mathrm{Mg}$ and Fe occupy the tetrahedral sites of plagioclase. In this study, for values of $\log \mathrm{f}_{\mathrm{O}_{2}}$ between -0.7 and -11.5 , the cationic contents of $\mathrm{Ca}+\mathrm{Na}+\mathrm{K}$ (oxygen $=8.0$ ) of plagioclases are approximately unity, suggesting that magnesium and ferrous and ferric iron are accommodated in the tetrahedral sites of plagioclase. They probably form the components $\mathrm{NaFeSi}_{3} \mathrm{O}_{8}, \mathrm{CaFe} 2 \mathrm{Si}_{2} \mathrm{O}_{8}$, and $\mathrm{Ca}(\mathrm{MgFe}) \mathrm{Si}_{3} \mathrm{O}_{8}$ in plagioclase. These provisional components may play an important role in the formulation of the partition coefficients of $\mathrm{Mg}$ and $\mathrm{Fe}$ between plagioclase and liquid as a function of $\mathrm{f}_{\mathrm{O}_{2}}$.

The $\mathrm{MgO}$ and $\mathrm{FeO}$ (total $\mathrm{Fe}$ as $\mathrm{FeO}$ ) contents of plagioclase of the experimental charges are plotted in Figure 1. The $\mathrm{MgO}$ contents of plagioclase are about $0.4 \mathrm{wt} \%$ and are not correlated with the $\mathrm{f}_{2}$ values of the run conditions. On the other hand, the $\mathrm{FeO}$ (total $\mathrm{Fe}$ as $\mathrm{FeO}$ ) contents of plagioclase vary with the $\mathrm{f}_{\mathrm{O}_{2}}$ conditions. The $\mathrm{FeO}$ contents of plagioclase are less than $0.3 \mathrm{wt} \%$ for reduced conditions, $0.4-0.7 \mathrm{wt} \%$ for fayalitemagnetite-quartz assemblage redox conditions, and up to $3 \mathrm{wt} \%$ for more oxidizing conditions (Fig. 1). This marked dependence was first noted by Longhi et al. (1976), based on the distribution coefficients of Fe between plagioclase and liquid in lunar and terrestrial basalts. In this work, the author conducted partitioning experiments in a much wider span of $\mathrm{f}_{\mathrm{O}_{2}}$ conditions to 


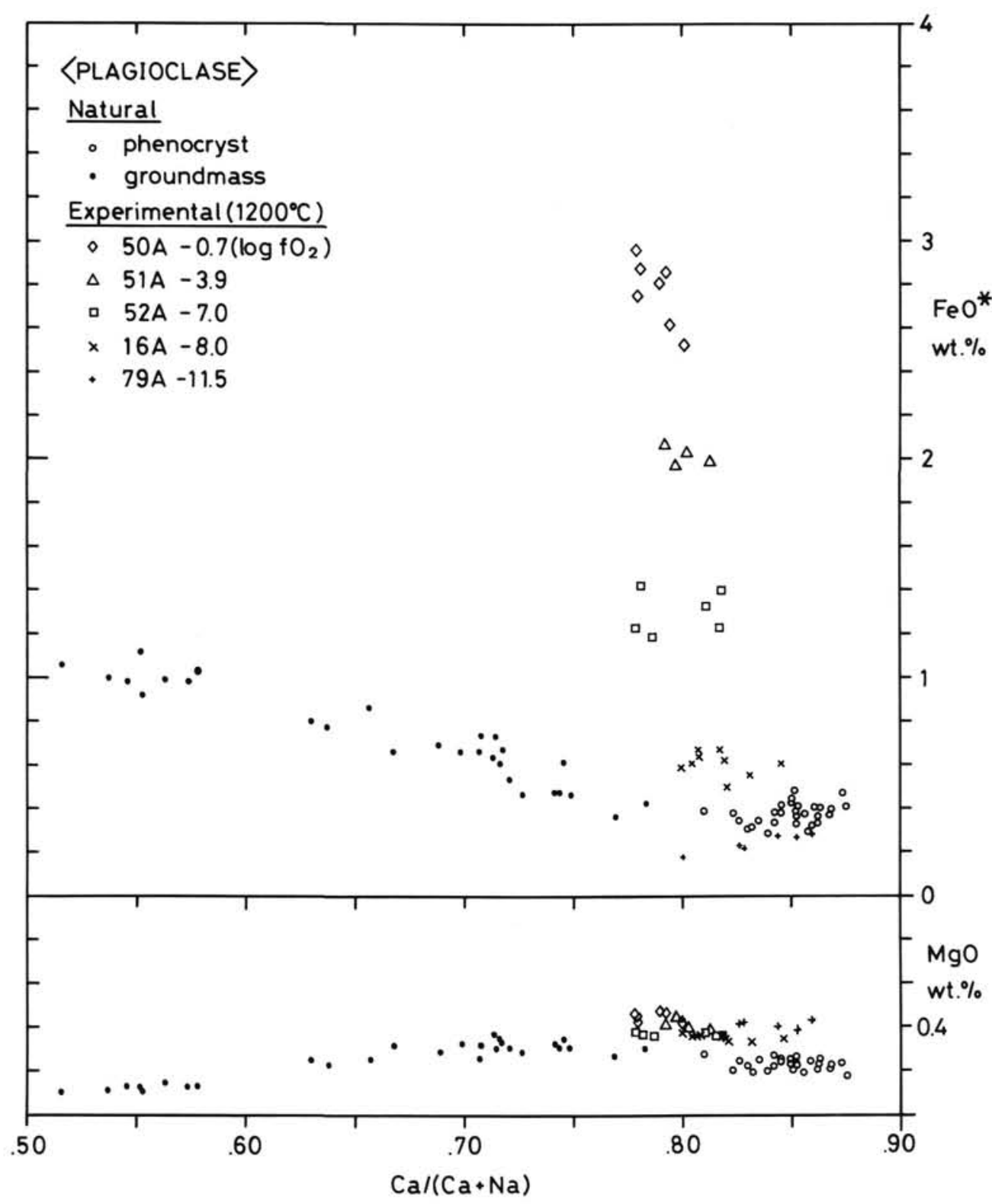

Figure 1. $\mathrm{MgO}$ and $\mathrm{FeO}$ contents of plagioclase in natural rocks and experimental charges. The variation of $\mathrm{MgO}$ and $\mathrm{FeO}$ contents of natural plagioclase are controlled by temperature, solution properties of plagioclase, and liquid composition. The plotted values from experimental plagioclase demonstrate the strong effect of $\mathrm{f}_{2}$ on the distribution of $\mathrm{FeO}$ in plagioclase. The discrepancy between the $\mathrm{MgO}$ abundances of natu$\mathrm{ral}$ and experimental plagioclases indicates the kinetic disequilibrium effect on element partitioning.

formulate the partitioning of $\mathrm{Mg}$ and $\mathrm{Fe}$ between plagioclase and liquid as a function of $\mathrm{f}_{\mathrm{O}_{2}}$.

The simple weight ratio distribution coefficients of $\mathrm{Mg}$ and Fe between plagioclase and liquid are shown in Figure 5, along with the partition coefficients observed in the natural samples (phenocryst and bulk rock). The distribution coefficients of $\mathrm{Mg}$ in the natural systems are distinctly lower than those in the experimental systems. This discrepancy implies that kinetic disequilibrium plays a role in the distribution of $\mathrm{Mg}$ between plagioclase and liquid. Because the experimental plagioclase crystallized at temperatures $30^{\circ}-70^{\circ} \mathrm{C}$ less than that of the liquidus, the degree of supersaturation is much larger than in the natural systems. The larger degree of supercooling of the experimental systems might have induced more rapid growth of plagioclase, which, in turn, promoted the incorporation of impurities
( $\mathrm{MgO}, \mathrm{FeO}$, etc.). The distribution coefficients determined by the experiments, therefore, may not represent the true equilibrium value, although the pseudoequilibrium conditions of the partitioning would be attained in terms of the exchange reaction of $\mathrm{Mg}$ and $\mathrm{Fe}$ between plagioclase and liquid, as discussed in the next section.

\section{FORMULATION OF THE PARTITION COEFFICIENTS OF MG AND FE BETWEEN PLAGIOCLASE AND LIQUID}

Kinetic disequilibrium of the partitioning of elements between crystals and liquids is caused both by the buildup of concentration gradients near growing crystals (Burton et al., 1953; Albarede and Bottinga, 1972) and by the boundary effects of crystal/liquid interfaces. The latter are commonly observed as 


\section{EXPERIMENTAL PROCEDURE}

1. fusion experiment

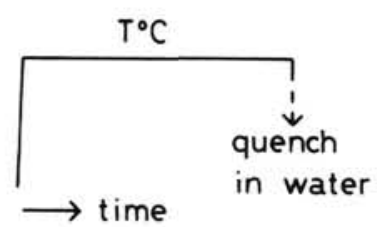

2. growth experiment

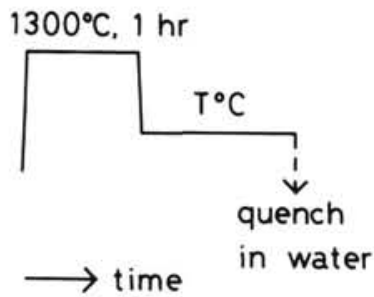

Figure 2. Experimental procedures used in this study.

sector zonings in igneous minerals (e.g., Nakamura, 1973; Hollister and Gancarz, 1970). Bryan (1974) described sector zonings of plagioclase in some ocean-floor basalts in which both $\mathrm{Mg}$ and $\mathrm{Fe}$ are concentrated in the (001) sectors in comparison with the $(010)$ sectors. The cooperative behaviors of $\mathrm{Mg}$ and $\mathrm{Fe}$ in sector-zoned plagioclase suggest that the interface effects are nearly equal for magnesium and iron.

The first cause of disequilibrium partitioning, the buildup of concentration gradients near growing crystals, is determined mainly by the diffusion coefficients and distribution coefficients of the elements involved. Burton et al. (1953) gave an equation of the effective distribution coefficient as

$$
D^{\prime}=D /(D+[1-D] \exp [-V d / R]),
$$

where $D$ is the equilibrium distribution coefficient and $V, d$, and $R$ are growth rate, thickness of diffusion layer, and diffusion coefficient of the element, respectively. Diffusion coefficients of $\mathrm{Mg}, \mathrm{Fe}^{2+}$, and $\mathrm{Fe}^{3+}$ are estimated to be $10^{-6.6}, 10^{-6.7}$, and $10^{-7.0} \mathrm{~cm}^{2} / \mathrm{s}$, according to the empirical correlation between $R$ and $Z^{2} r$ (Hofmann, 1980), where $Z$ is the valence and $r$ is the ionic radius of elements. Equilibrium distribution coefficients of $\mathrm{Mg}, \mathrm{Fe}^{2+}$, and $\mathrm{Fe}^{3+}$ are provisionally calculated to be $0.042,0.012$, and 0.66 , based on the model formulation discussed in the following paragraph. $V$, the growth rate, is on the order of $3 \times 10^{-5} \mathrm{~cm}^{2} / \mathrm{s}$ (Dowty, 1980), whereas $d$, the thickness of the diffusion layer, is supposed to be $10^{-3} \mathrm{~cm}$. From these values, the departure of the effective distribution coefficients from the equilibrium distribution coefficients are calculated as $D^{\prime} / D$ to be $1.12,1.16$, and 1.09 for $\mathrm{Mg}, \mathrm{Fe}^{2+}$, and $\mathrm{Fe}^{3+}$, respectively. Although the variables such as the growth rate may differ from one experiment to another, the sense and magnitude of the departure from equilibrium would be similar for the distribution coefficients of $\mathrm{Mg}, \mathrm{Fe}^{2+}$, and $\mathrm{Fe}^{3+}$ in a crystallizing system. Therefore, in considering the exchange partition coefficient of $\mathrm{Mg}$ and $\mathrm{Fe}$ between plagioclase and liquid, $K=(\mathrm{Mg} / \mathrm{Fe})_{\text {plagioclase }} /(\mathrm{Mg} / \mathrm{Fe})_{\text {liquid }}$, the disequilibrium effects are much less than in the case of simple ratio distribution coefficients.

As noted previously, $\mathrm{Mg}$ and ferrous iron are incorporated in plagioclase as a $\mathrm{Ca}(\mathrm{Mg}, \mathrm{Fe}) \mathrm{Si}_{3} \mathrm{O}_{8}$ component, whereas ferric iron may go into plagioclase as $\mathrm{NaFeSi}_{3} \mathrm{O}_{8}$ or $\mathrm{CaFe}_{2} \mathrm{Si}_{2} \mathrm{O}_{8}$ compo- nents. Therefore, the equilibrium exchange reactions are formulated as follows:

$$
\begin{gathered}
\mathrm{CaMgSi}_{3} \mathrm{O}_{8}+\mathrm{FeO}=\mathrm{CaFeSi}_{3} \mathrm{O}_{8}+\mathrm{MgO} \\
\mathrm{NaFeSi}_{3} \mathrm{O}_{8}+0.5 \mathrm{Al}_{2} \mathrm{O}_{3}=\mathrm{NaAlSi}_{3} \mathrm{O}_{8}+0.5 \mathrm{Fe}_{2} \mathrm{O}_{3}
\end{gathered}
$$

Assuming that the activity coefficients of the components in plagioclase and melt are constant, an exchange partition coefficient of $\mathrm{Mg}$ and $\mathrm{Fe}$ between plagioclase and magma can be formulated by a linear combination of the preceding reactions using the equation of redox states of iron in liquid of Kilinc et al. (1983). From the compositional data of runs $42 \mathrm{~A}\left(\mathrm{f}_{\mathrm{O}_{2}}=10^{-7}\right)$ and $79 \mathrm{~A}\left(\mathrm{f}_{\mathrm{O}_{2}}=10^{-11.5}\right)$, the apparent reaction constants of equations (1) and (2) are 4.09 and 3.49, respectively. The distribution coefficients of $\mathrm{Mg}, \mathrm{Fe}^{2+}$, and $\mathrm{Fe}^{3+}$ are $0.042,0.012$, and 0.66 , respectively. However, this model does not fit all of the experimental data, in part because of the nonideal behavior of the $\mathrm{Mg}$ and $\mathrm{Fe}$ components in plagioclase solid solution, and in part because of the probable decomposition reaction of ferric-rich plagioclase under oxidized conditions. Therefore, an empirical approach was taken in this study in estimating the redox state of magmas.

The exchange partition coefficient of $\mathrm{Mg}$ and total $\mathrm{Fe}$ between plagioclase and liquid as a function of $\mathrm{f}_{\mathrm{O}_{2}}$ is plotted in Figure 6 . The figure demonstrates a good correlation between the exchange partition coefficient and $\mathrm{f}_{2}$. However, any additional dependence of the partition coefficient on temperature and composition of the phases has not been resolved. Accordingly, Figure 6 applies only to estimating the approximate redox conditions of ocean floor basalt.

\section{REDOX CONDITIONS OF LEG 111 BASALT SAMPLES}

The natural logarithms of the exchange partition coefficients of $\mathrm{Mg}$ and total $\mathrm{Fe}$ between plagioclase and bulk-rock samples (Table 1) are from -0.50 to -0.55 . Applying the relation in Figure 6 results in an $\mathrm{f}_{2}$ for the Hole 504B basalt samples that coincides with those defined by fayalite-quartz-magnetite buffer assemblage. Longhi et al. (1976) reported the natural logarithm of the average exchange partition coefficient for mid-ocean ridge basalts as -0.34 , which corresponds to slightly more reducing conditions than that of fayalite-magnetite-quartz buffer assemblage in application to the experimental data (Fig. 5).

Christie et al. (1986) discussed the redox states of oceanridge basalts based on the ferric/ferrous ratios of freshly chilled margin glasses. Their results indicate that most of these $\mathrm{f}_{\mathrm{O}_{2}}$ values are $0-2$ orders of magnitude lower than those of the fayalitemagnetite-quartz assemblage. The overall results of this study harmonize with Christie et al.'s (1986) results. Whereas the method of $\mathrm{Mg}-\mathrm{Fe}$ exchange partitioning between phenocryst plagioclase and bulk-rock composition may give information about the intratelluric phenocryst crystallization stage of magma evolution, the method of Christie et al. (1986; after Kilinc et al., 1983) records the conditions of erupted magmas. In addition, the estimation of the redox states of magmas by $\mathrm{Mg}$-Fe exchange partitioning between plagioclase and liquid is widely applicable because of the widespread occurrences of plagioclase phenocrysts in volcanic rocks and the apparently low susceptibility of the $\mathrm{Mg}$ and $\mathrm{Fe}$ contents in basalt and plagioclase to alteration.

\section{ACKNOWLEDGMENTS}

I acknowledge Prof. H. Sakai, Dr. H. Ishizuka, and Prof. K. Sada for respectively critiquing the manuscript, selecting fresh samples for this study, and providing encouragement. Comments by Dr. J. Longhi and an anonymous reviewer were helpful in improving the manuscript. 
Table 2. Experimental results of Leg 111 basalt samples.

\begin{tabular}{|c|c|c|c|c|c|c|c|c|}
\hline \multirow[b]{2}{*}{ Run } & \multirow[b]{2}{*}{$\begin{array}{c}\text { Temperature } \\
\left({ }^{\circ} \mathrm{C}\right)\end{array}$} & \multirow[b]{2}{*}{$\begin{array}{c}\mathrm{Log} \\
\mathrm{f}_{\mathrm{O}_{2}}\end{array}$} & \multirow[b]{2}{*}{$\begin{array}{c}\text { Duration } \\
\text { (hr) }\end{array}$} & \multicolumn{5}{|c|}{ Phases $^{\mathrm{a}}(\%)$} \\
\hline & & & & Glass & $\begin{array}{l}\text { Calcium-rich } \\
\text { plagioclase }\end{array}$ & Olivine & Clinopyroxene & Magnetite \\
\hline \multicolumn{9}{|c|}{ Sample 111-504B-143R-2 (Piece 8) } \\
\hline \multicolumn{9}{|c|}{ Fusion experiment } \\
\hline $\begin{array}{l}04 \mathrm{~A} \\
05 \mathrm{~A} \\
06 \mathrm{~A} \\
08 \mathrm{~A} \\
09 \mathrm{~A} \\
10 \mathrm{~A} \\
12 \mathrm{~A} \\
13 \mathrm{~A} \\
14 \mathrm{~A} \\
22 \mathrm{~A} \\
43 \mathrm{~A}\end{array}$ & $\begin{array}{l}1200 \\
1250 \\
1240 \\
1180 \\
1230 \\
1220 \\
1150 \\
1210 \\
1190 \\
1255 \\
1300\end{array}$ & $\begin{array}{l}-8.0 \\
-8.0 \\
-8.0 \\
-8.0 \\
-8.0 \\
-8.0 \\
-8.0 \\
-8.0 \\
-8.0 \\
-8.0 \\
-0.7\end{array}$ & $\begin{array}{r}9.0 \\
1.0 \\
2.1 \\
13.0 \\
1.4 \\
1.0 \\
9.2 \\
12.3 \\
10.6 \\
3.5 \\
0.6\end{array}$ & $\begin{array}{r}60 \\
>99 \\
99 \\
30 \\
90 \\
75 \\
10 \\
60 \\
40 \\
100 \\
100\end{array}$ & $\begin{array}{r}20 \\
<1 \\
1 \\
40 \\
10 \\
20 \\
50 \\
30 \\
40 \\
- \\
-\end{array}$ & $\begin{array}{l}\bar{z} \\
\overline{-} \\
\overline{-} \\
\bar{?} \\
\overline{-} \\
\overline{-}\end{array}$ & $\begin{array}{r}20 \\
- \\
30 \\
<1 \\
5 \\
40 \\
10 \\
20 \\
- \\
-\end{array}$ & $\begin{array}{l}- \\
\bar{z} \\
- \\
- \\
z \\
\overline{-} \\
-\end{array}$ \\
\hline \multicolumn{9}{|c|}{ Growth experiment } \\
\hline $\begin{array}{l}15 \mathrm{~A} \\
16 \mathrm{~A} \\
17 \mathrm{~A} \\
19 \mathrm{~A} \\
24 \mathrm{~A} \\
25 \mathrm{~A} \\
26 \mathrm{~A} \\
34 \mathrm{~A} \\
35 \mathrm{~A} \\
41 \mathrm{~A} \\
42 \mathrm{~A} \\
45 \mathrm{~A} \\
46 \mathrm{~A} \\
48 \mathrm{~A} \\
50 \mathrm{~A} \\
51 \mathrm{~A} \\
52 \mathrm{~A} \\
79 \mathrm{~A}\end{array}$ & $\begin{array}{l}1220 \\
1200 \\
1240 \\
1230 \\
1210 \\
1240 \\
1220 \\
1180 \\
1200 \\
1220 \\
1220 \\
1220 \\
1220 \\
1230 \\
1200 \\
1200 \\
1200 \\
1200\end{array}$ & $\begin{array}{r}-8.0 \\
-8.0 \\
-8.0 \\
-8.0 \\
-8.0 \\
-6.0 \\
-6.0 \\
-8.8 \\
-10.0 \\
-9.7 \\
-7.0 \\
-9.0 \\
-8.0 \\
-8.0 \\
-0.7 \\
-3.9 \\
-7.0 \\
-11.5\end{array}$ & $\begin{array}{l}47.4 \\
73.0 \\
35.1 \\
23.6 \\
25.0 \\
13.0 \\
19.5 \\
24.7 \\
32.1 \\
26.4 \\
34.5 \\
39.5 \\
39.5 \\
24.4 \\
42.9 \\
42.1 \\
42.9 \\
97.5\end{array}$ & $\begin{array}{r}98 \\
77 \\
100 \\
100 \\
99 \\
100 \\
95 \\
73 \\
88 \\
99 \\
100 \\
>99 \\
>99 \\
100 \\
83 \\
84 \\
85 \\
78\end{array}$ & $\begin{array}{r}2 \\
20 \\
-\overline{1} \\
-\frac{5}{5} \\
20 \\
10 \\
1 \\
-\overline{<} \\
<1 \\
-15 \\
15 \\
15 \\
20\end{array}$ & $\begin{array}{l}\overline{3} \\
\overline{-} \\
- \\
\overline{-} \\
5 \\
\frac{2}{-} \\
\overline{-} \\
\overline{-} \\
\overline{-} \\
\overline{2} \\
2\end{array}$ & $\begin{array}{l}- \\
= \\
- \\
- \\
\overline{2} \\
= \\
= \\
= \\
= \\
= \\
- \\
-\end{array}$ & $\begin{array}{l}- \\
= \\
= \\
= \\
= \\
= \\
= \\
= \\
= \\
- \\
2 \\
1 \\
<1 \\
-\end{array}$ \\
\hline \multicolumn{9}{|c|}{ Sample 111-504B-169R-1 (Piece 1) } \\
\hline \multicolumn{9}{|c|}{ Fusion experiment } \\
\hline $\begin{array}{l}03 \mathrm{~B} \\
04 \mathrm{~B} \\
08 \mathrm{~B} \\
09 \mathrm{~B} \\
10 \mathrm{~B} \\
11 \mathrm{~B} \\
12 \mathrm{~B} \\
13 \mathrm{~B} \\
14 \mathrm{~B} \\
44 \mathrm{~B}\end{array}$ & $\begin{array}{l}1240 \\
1200 \\
1180 \\
1230 \\
1220 \\
1210 \\
1150 \\
1210 \\
1190 \\
1300\end{array}$ & $\begin{array}{l}-7.5 \\
-8.0 \\
-8.0 \\
-8.0 \\
-8.0 \\
-8.0 \\
-8.0 \\
-8.0 \\
-8.0 \\
-0.7\end{array}$ & $\begin{array}{r}3.4 \\
9.0 \\
13.0 \\
1.4 \\
1.0 \\
2.8 \\
9.2 \\
12.3 \\
10.6 \\
0.4\end{array}$ & $\begin{array}{r}100 \\
82 \\
60 \\
99 \\
95 \\
93 \\
10 \\
95 \\
60 \\
100\end{array}$ & $\begin{array}{r}\overline{15} \\
30 \\
1 \\
5 \\
7 \\
50 \\
5 \\
30 \\
-\end{array}$ & $\begin{array}{l}\overline{-} \\
- \\
\overline{-} \\
\overline{-} \\
\bar{?} \\
\overline{-}\end{array}$ & $\begin{array}{l}\overline{3} \\
10 \\
- \\
\overline{-} \\
\overline{40} \\
\overline{10} \\
-\end{array}$ & $\begin{array}{l}- \\
- \\
- \\
z \\
- \\
- \\
-\end{array}$ \\
\hline \multicolumn{9}{|c|}{ Growth experiment } \\
\hline $\begin{array}{l}05 \mathrm{~B} \\
16 \mathrm{~B} \\
18 \mathrm{~B} \\
19 \mathrm{~B} \\
24 \mathrm{~B} \\
26 \mathrm{~B} \\
34 \mathrm{~B} \\
35 \mathrm{~B} \\
39 \mathrm{~B} \\
41 \mathrm{~B} \\
42 \mathrm{~B} \\
45 \mathrm{~B} \\
46 \mathrm{~B} \\
47 \mathrm{~B} \\
48 \mathrm{~B} \\
50 \mathrm{~B} \\
51 \mathrm{~B} \\
52 \mathrm{~B} \\
79 \mathrm{~B}\end{array}$ & $\begin{array}{l}1220 \\
1200 \\
1240 \\
1230 \\
1210 \\
1220 \\
1180 \\
1200 \\
1250 \\
1220 \\
1220 \\
1220 \\
1220 \\
1200 \\
1230 \\
1200 \\
1200 \\
1200 \\
1200\end{array}$ & $\begin{array}{r}-8.0 \\
-8.0 \\
-8.0 \\
-8.0 \\
-8.0 \\
-6.0 \\
-8.8 \\
-10.0 \\
-8.0 \\
-9.7 \\
-7.0 \\
-9.0 \\
-8.0 \\
-8.0 \\
-8.0 \\
-0.7 \\
-3.9 \\
-7.0 \\
-11.5\end{array}$ & $\begin{array}{l}47.4 \\
73.0 \\
31.5 \\
23.6 \\
25.0 \\
19.5 \\
24.7 \\
32.1 \\
25.1 \\
26.4 \\
34.5 \\
39.5 \\
39.5 \\
23.0 \\
24.4 \\
42.9 \\
42.1 \\
42.9 \\
97.5\end{array}$ & $\begin{array}{r}100 \\
95 \\
100 \\
100 \\
100 \\
100 \\
95 \\
99 \\
100 \\
100 \\
100 \\
100 \\
100 \\
>99 \\
100 \\
93 \\
97 \\
98 \\
98\end{array}$ & $\begin{array}{l}- \\
-5 \\
- \\
- \\
-5 \\
1 \\
- \\
\overline{-} \\
- \\
<1 \\
-5 \\
3 \\
2 \\
2\end{array}$ & $\begin{array}{l}- \\
= \\
= \\
= \\
= \\
= \\
= \\
= \\
= \\
= \\
= \\
-\end{array}$ & 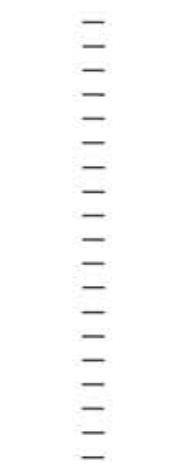 & $\begin{array}{l}- \\
= \\
- \\
= \\
- \\
- \\
- \\
- \\
- \\
- \\
- \\
2 \\
<1 \\
<1 \\
-\end{array}$ \\
\hline
\end{tabular}

${ }^{\text {a }}$ Estimated by microscopic observation.

This work was supported in part by funds from the Cooperative Program (No. 87107), provided by Ocean Research Institute, University of Tokyo, as well as from a Scientific Grant of the Ministry of Education, Science and Culture of Japan (No. 61540593).

\section{REFERENCES}

Albarede, F., and Bottinga, Y., 1972. Kinetic disequilibrium in trace element partitioning between phenocrysts and host lava. Geochim. Cosmochim. Acta, 36:141-156.
Autio, L. K., and Rhodes, J. M., 1982. Costa Rica Rift Zone basalts: geochemical and experimental data from a possible example of multistage melting. In Cann, J. R., Langseth, M. G., Honnorez, J., Von Herzen, R. P., White, S. M., et al., Init. Repts. DSDP, 69: Washington (U.S. Govt. Printing Office), 729-745.

Baker, M. B., and Grove, T. L., 1985. Kinetic controls on pyroxene nucleation and metastable liquid lines of descent in a basaltic andesite. Am. Mineral., 70:279-287.

Bryan, W. B., 1974. Fe, Mg relationships in sector-zoned submarine basalt plagioclase. Earth Planet. Sci. Lett., 24:157-165. 
Burton, J. A., Prim, R. C., and Slichter, W. P., 1953. The distribution of solute in crystals grown from the melt. Part I. Theoretical. J. Chem. Phys., 21:1987-1991.

Christie, D. M., Carmichael, I.S.E., and Langmuir, C. H., 1986. Oxidation states of mid-ocean ridge basalt glasses. Earth Planet. Sci. Lett., 79:397-411.

Donaldson, C. H., 1979. An experimental investigation of the delay in nucleation of olivine in mafic magmas. Contrib. Mineral. Petrol., 69:21-32.

Donaldson, C. H., Williams, R. J., and Lofgren, G., 1975. A sample holding technique for study of crystal growth in silicate melts. $\mathrm{Am}$. Mineral., 60:324-326.

Dowty, E., 1980. Crystal growth and nucleation theory and the numerical simulation of igneous crystallization. In Hargraves, R. B. (Ed.), Physics of Magmatic Processes: Princeton, NJ (Princeton Univ. Press), 419-485.

Drake, M. J., and Weill, D. F., 1975. The partition of $\mathrm{Sr}, \mathrm{Ba}, \mathrm{Ca}, \mathrm{Y}$, $\mathrm{Eu}^{2+}, \mathrm{Eu}^{3+}$, and other REE between plagioclase feldspar and magmatic silicate liquid: an experimental study. Geochim. Cosmochim. Acta, 39:689-712.

Elthon, D., and Casey, J. F., 1985. The very depleted nature of certain primary mid-ocean ridge basalts. Geochim. Cosmochim. Acta, 49: 289-298.

Fukuyama, H., and Hamuro, K., 1978. Melting relations of Leg 46 basalts at atmospheric pressure. In Dmitriev, L., Heirtzler, J., et al., Init. Repts. DSDP, 46: Washington (U.S. Govt. Printing Office), 235-239.

Gibb, F.G.F., 1974. Supercooling and the crystallization of plagioclase from a basaltic magma. Mineral. Mag., 39:641-653.

Grove, T. L., and Bryan, W. B., 1983. Fractionation of pyroxene-phyric MORB at low pressure: an experimental study. Contrib. Mineral. Petrol., 84:293-309.

Hofmann, A. W., 1980. Diffusion in natural silicate melts: a critical review. In Hargraves, R. B. (Ed.), Physics of magmatic processes: Princeton, NJ (Princeton Univ. Press), 385-417.

Hollister, L. S., and Gancarz, A. J., 1970. Compositional sector-zoning in clinopyroxene from the Narce area, Italy. Am. Mineral., 56:959979.

Kilinc, A., Carmichael, I.S.E., Rivers, M. L., and Sack, R. O., 1983. The ferric-ferrous ratio of natural silicate liquids equilibrated in air. Contrib. Mineral. Petrol., 83:136-140.

Longhi, J., Walker, D., and Hays, J. F., 1976. Fe and Mg in plagioclase. Geochim. Cosmochim. Acta, Supp., 7:1281-1300.

Nafziger, R. H., Ulmer, G. C., and Woermann, E., 1971. Gaseous buffering for the control of oxygen fugacity at one atmosphere. In Ulmer, G. C. (Ed.), Research Techniques for High Pressure and High Temperature: New York (Springer), 9-41.

Nakamura, Y., 1973. Origin of sector-zoning of igneous clinopyroxenes. Am. Mineral., 58:986-990.

Natland, J. H., Adamson, A. C., Laverne, C., Melson, W. G., and O'Hearn, T., 1982. A compositionally nearly steady-state magma chamber at the Costa Rica Rift: evidence from basalt glass and mineral data, Deep Sea Drilling Project Sites 501, 504, and 505. In Cann, J. R., Langseth, M. G., Honnorez, J., Von Herzen, R. P., White, S. M., et al., Init. Repts. DSDP, 69: Washington (U.S. Govt. Printing Office), 811-858.

Presnall, D. C., and Brenner, N. L., 1974. A method for studying iron silicate liquids under reducing conditions with negligible iron loss. Geochim. Cosmochim. Acta, 38:1785-1788.

Tormey, D. R., Grove, T. L., and Bryan, W. B., 1987. Experimental petrology of normal MORB near the Kane Fracture Zone: $22^{\circ}-25^{\circ} \mathrm{N}$, Mid-Atlantic Ridge. Contrib. Mineral. Petrol., 96:121-139.
Tsuchiyama, A., 1983. Crystallization kinetics in the system $\mathrm{CaMgSi}_{2} \mathrm{O}_{6}$ $\mathrm{CaAl}_{2} \mathrm{Si}_{2} \mathrm{O}_{8}$ : the delay in nucleation of diopside and anorthite. $\mathrm{Am}$. Mineral., 68:687-698.

Walker, D., Shibata, T., and DeLong, S. E., 1979. Abyssal tholeiites from the Oceanographer Fracture Zone. II. Phase equilibria and mixing. Contrib. Mineral. Petrol., 70:111-125.

Date of initial receipt: 25 April 1988 Date of acceptance: 31 October 1988 Ms 111B-113

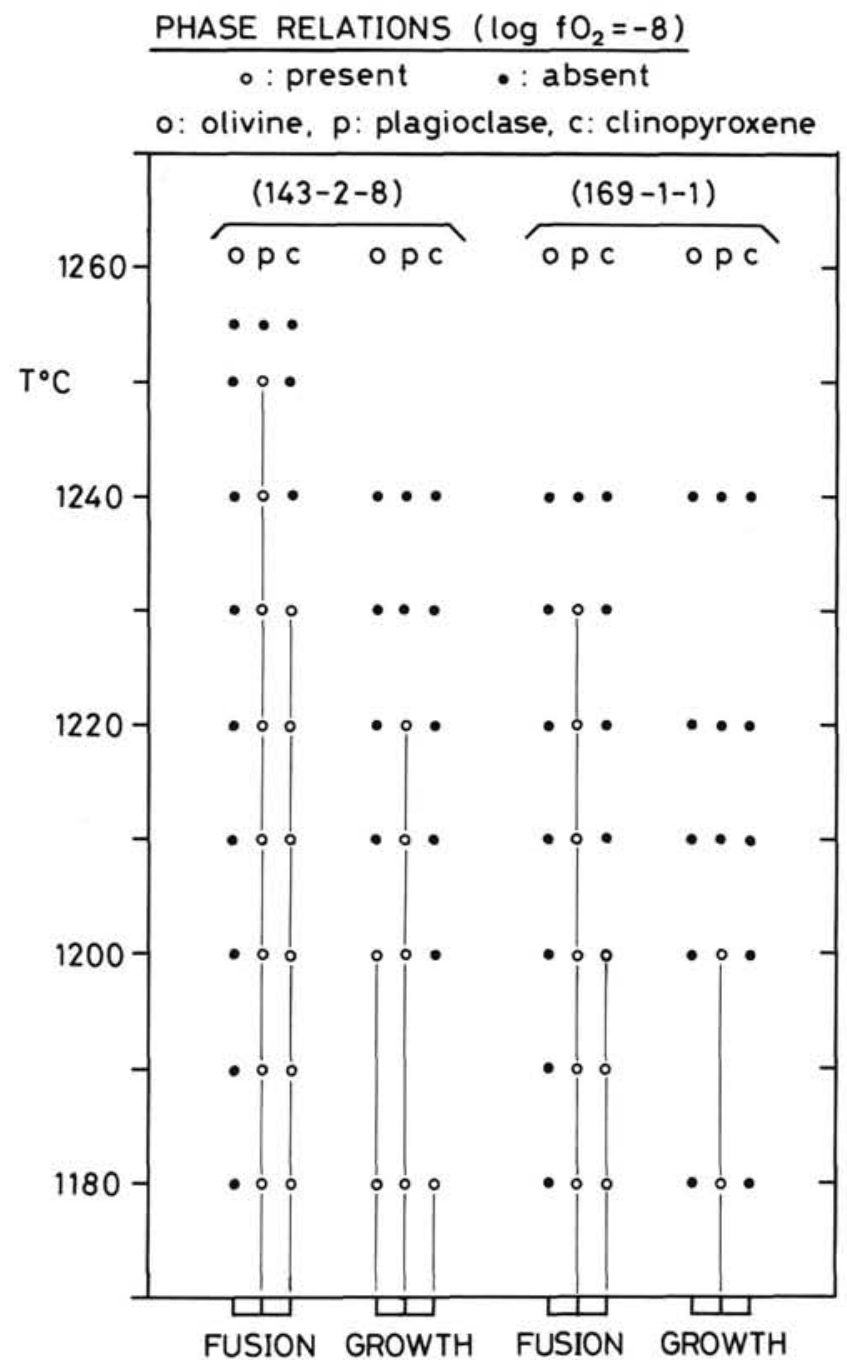

Figure 3. Phase relations of Leg 111 ocean-floor basalts from two Hole 504B samples. The discrepancy between the results of the fusion and growth experiments is due largely to the delay of nucleation and growth in the latter method. 
Table 3. Electron microprobe analyses of run products from experiments on ODP Leg 111 basalts. See Table 2 for run conditions.

\begin{tabular}{|c|c|c|c|c|c|c|c|c|c|c|c|c|c|}
\hline $\begin{array}{c}\text { Run } \\
\text { Phase }\end{array}$ & $\begin{array}{c}\text { Averaged } \\
\text { analyses }\end{array}$ & $\mathrm{SiO}_{2}$ & $\mathrm{TiO}_{2}$ & $\mathrm{Al}_{2} \mathrm{O}_{3}$ & $\mathrm{FeO}^{*}$ & $\mathrm{MnO}$ & $\mathrm{MgO}$ & $\mathrm{CaO}$ & $\mathrm{Na}_{2} \mathrm{O}$ & $\mathrm{K}_{2} \mathrm{O}$ & $\mathrm{P}_{2} \mathrm{O}_{5}$ & Others & Total \\
\hline \multicolumn{14}{|c|}{ Sample 111-504B-143R-2 (Piece 8) } \\
\hline $15 \mathrm{~A} \mathrm{gl}$ & 12 & $49.35(26)$ & $0.84(04)$ & $15.71(25)$ & $8.22(28)$ & $0.22(03)$ & $9.42(19)$ & $13.39(12)$ & $1.49(04)$ & $0.01(01)$ & & & 98.65 \\
\hline $\mathrm{pl}$ & 9 & $47.93(26)$ & $0.03(01)$ & $32.34(22)$ & $0.42(05)$ & $0.04(02)$ & $0.35(02)$ & $17.12(18)$ & $1.86(06)$ & $0.00(00)$ & & & 100.09 \\
\hline $16 \mathrm{~A} \mathrm{gl}$ & 11 & $50.11(32)$ & $1.18(04)$ & $14.17(18)$ & $9.37(25)$ & $0.20(03)$ & $8.85(19)$ & $13.26(23)$ & $1.58(03)$ & $0.02(02)$ & & & 98.74 \\
\hline $\mathrm{pl}$ & 10 & $48.01(61)$ & $0.04(02)$ & $32.21(26)$ & $0.65(13)$ & $0.01(01)$ & $0.34(04)$ & $16.76(26)$ & $2.03(21)$ & $0.01(01)$ & & & 100.06 \\
\hline ol & 16 & $39.48(19)$ & $0.00(00)$ & $0.05(01)$ & $13.21(34)$ & $0.18(02)$ & $46.50(46)$ & $0.33(02)$ & $0.03(01)$ & & & $\mathrm{NiO} 0.15(02)$ & 99.93 \\
\hline $26 \mathrm{~A} \mathrm{gl}$ & 23 & $48.74(27)$ & $0.86(05)$ & $14.94(31)$ & $8.96(20)$ & $0.22(03)$ & 9.57 (17) & $13.19(17)$ & $1.60(05)$ & $0.01(01)$ & & & 98.09 \\
\hline $\mathrm{pl}$ & 14 & $47.81(36)$ & $0.05(01)$ & $30.89(25)$ & $1.88(06)$ & $0.05(01)$ & $0.38(03)$ & $16.80(25)$ & $1.92(10)$ & $0.00(00)$ & & & 99.78 \\
\hline $34 \mathrm{~A} \mathrm{gl}$ & 7 & 50.60 & $1.38(06)$ & $13.29(17)$ & $10.63(19)$ & $0.21(02)$ & $7.81(19)$ & $13.30(14)$ & $1.81(08)$ & $0.02(01)$ & & & 99.05 \\
\hline $\mathrm{pl}$ & 7 & $49.30(39)$ & $0.02(02)$ & $31.72(28)$ & $0.75(11)$ & $0.02(01)$ & $0.41(06)$ & $16.24(30)$ & $2.40(07)$ & $0.01(01)$ & & & 100.87 \\
\hline ol & 7 & $39.18(40)$ & $0.01(02)$ & $0.07(02)$ & $16.09(52)$ & $0.28(04)$ & $44.34(65)$ & $0.42(03)$ & $0.02(01)$ & $\mathrm{Cr}_{2} \mathrm{O}_{3} 0.04(02)$ & & $\mathrm{NiO} 0.10(02)$ & 100.55 \\
\hline cp & 2 & $52.78(09)$ & $0.48(02)$ & $3.28(44)$ & $6.78(05)$ & $0.22(02)$ & $18.68(49)$ & $18.78(86)$ & $0.14(02)$ & & & $\mathrm{Cr}_{2} \mathrm{O}_{3} 0.22(07)$ & 101.36 \\
\hline $35 \mathrm{~A} \mathrm{gl}$ & 5 & $50.38(57)$ & $1.14(06)$ & $14.79(31)$ & $8.82(19)$ & $0.17(04)$ & $8.73(47)$ & $13.37(09)$ & $1.64(04)$ & $0.02(00)$ & & & 99.06 \\
\hline $\mathrm{pl}$ & 8 & $48.31(50)$ & $0.00(01)$ & 32.42 (19) & $0.32(06)$ & $0.02(01)$ & $0.35(02)$ & $16.57(21)$ & $2.19(07)$ & $0.01(01)$ & & & 100.19 \\
\hline ol & 13 & $39.49(58)$ & $0.00(00)$ & $0.06(01)$ & $13.65(33)$ & $0.17(03)$ & $46.28(46)$ & 0.37 (02) & $0.03(01)$ & $\mathrm{Cr}_{2} \mathrm{O}_{3} 0.05(02)$ & & $\mathrm{NiO} 0.07(02)$ & 100.17 \\
\hline $41 \mathrm{~A} \mathrm{gl}$ & 5 & $49.90(13)$ & $0.86(03)$ & $16.23(12)$ & $7.40(08)$ & $0.11(01)$ & $9.31(12)$ & 13.35 (14) & $1.49(02)$ & $0.01(01)$ & & & 98.66 \\
\hline & 5 & $47.90(30)$ & $0.01(01)$ & $32.40(16)$ & $0.30(05)$ & $0.00(00)$ & $0.37(01)$ & $16.68(07)$ & $1.99(05)$ & $0.01(00)$ & & & 99.66 \\
\hline $45 \mathrm{~A} \mathrm{gl}$ & 6 & $49.74(14)$ & $0.83(01)$ & $16.17(23)$ & 7.77 (13) & $0.12(02)$ & $9.18(09)$ & $13.22(13)$ & $1.60(03)$ & $0.01(00)$ & & & 98.64 \\
\hline pl & 5 & $48.22(25)$ & $0.02(01)$ & $32.48(14)$ & $0.36(03)$ & $0.00(00)$ & $0.35(01)$ & $16.60(08)$ & $2.12(09)$ & $0.00(00)$ & & & 100.15 \\
\hline $46 \mathrm{~A} \mathrm{gl}$ & 8 & $49.48(31)$ & $0.89(06)$ & $15.85(31)$ & $8.12(11)$ & $0.12(03)$ & 9.31 (11) & 13.20 (12) & $1.70(06)$ & $0.02(01)$ & & & 98.69 \\
\hline pl & 8 & $48.04(28)$ & $0.03(02)$ & 32.43 (11) & $0.41(03)$ & $0.00(00)$ & $0.37(01)$ & $16.70(20)$ & $2.07(05)$ & $0.01(00)$ & & & 100.06 \\
\hline $50 \mathrm{~A} \mathrm{gl}$ & 6 & $50.28(21)$ & $1.14(02)$ & $13.31(13)$ & $8.58(22)$ & $0.17(02)$ & $10.42(15)$ & $12.90(07)$ & $1.65(07)$ & $0.01(00)$ & $0.09(02)$ & & 98.55 \\
\hline $\mathrm{pl}$ & 7 & $48.62(10)$ & $0.03(02)$ & 29.90 (23) & 2.77 (15) & $0.00(00)$ & $0.45(02)$ & 16.07 (25) & $2.40(09)$ & $0.00(00)$ & $0.05(04)$ & & 100.29 \\
\hline $\mathrm{mt}$ & 9 & $0.14(02)$ & $0.57(03)$ & $9.86(66)$ & $61.40(93)$ & $0.36(03)$ & $17.63(54)$ & $0.08(03)$ & $0.02(01)$ & $\mathrm{Cr}_{2} \mathrm{O}_{3} 2.59$ (37) & 0.27 & $\mathrm{NiO} 0.43(05)$ & 93.08 \\
\hline $51 \mathrm{~A} \mathrm{gl}$ & 5 & $49.60(20)$ & $1.05(02)$ & $13.84(10)$ & $9.44(12)$ & $0.15(02)$ & $10.23(05)$ & $12.82(17)$ & $1.57(10)$ & $0.01(00)$ & $0.08(03)$ & & 98.79 \\
\hline $\mathrm{pl}$ & 4 & $48.53(20)$ & $0.01(01)$ & $30.72(25)$ & $2.01(04)$ & $0.00(00)$ & $0.41(03)$ & 16.43 (17) & $2.26(10)$ & $0.00(00)$ & $0.04(03)$ & & 100.41 \\
\hline $\mathrm{mt}$ & 2 & 0.15 & 0.67 & 10.76 & 57.07 & 0.24 & 14.55 & 0.18 & 0.01 & $\mathrm{Cr}_{2} \mathrm{O}_{3} 10.10$ & & $\mathrm{NiO} 0.41$ & 94.14 \\
\hline $52 \mathrm{~A} \mathrm{gl}$ & 7 & $49.61(24)$ & $1.07(03)$ & $13.92(16)$ & $9.53(26)$ & $0.15(03)$ & $10.24(10)$ & $12.67(06)$ & $1.69(03)$ & $0.01(00)$ & $0.12(02)$ & & 99.01 \\
\hline $\mathrm{pl}$ & 6 & $43.43(54)$ & $0.01(02)$ & $31.48(28)$ & $1.30(09)$ & $0.00(00)$ & $0.37(01)$ & $16.48(33)$ & $2.30(20)$ & $0.00(00)$ & $0.04(02)$ & & 100.41 \\
\hline $\mathrm{mt}$ & 1 & 0.15 & 0.70 & 11.69 & 55.12 & 0.23 & 13.96 & 0.23 & 0.01 & $\mathrm{Cr}_{2} \mathrm{O}_{3} 12.15$ & 0.24 & $\mathrm{NiO} 0.39$ & 94.87 \\
\hline $79 \mathrm{~A} \mathrm{gl}$ & 7 & $51.96(58)$ & $1.29(04)$ & $13.97(15)$ & $7.90(34)$ & $0.16(02)$ & $8.56(12)$ & $13.77(12)$ & $0.84(02)$ & $0.01(00)$ & $0.07(04)$ & & 98.53 \\
\hline $\mathrm{pl}$ & 6 & $48.49(61)$ & $0.01(01)$ & $32.45(22)$ & $0.24(04)$ & $0.00(00)$ & $0.42(02)$ & 17.07 (34) & $1.87(23)$ & $0.00(00)$ & & & 100.55 \\
\hline ol & 4 & $39.56(16)$ & $0.00(01)$ & $0.11(01)$ & $13.62(14)$ & $0.21(01)$ & $45.77(25)$ & $0.37(02)$ & $0.01(00)$ & $\mathrm{Cr}_{2} \mathrm{O}_{3} 0.05(00)$ & & $\mathrm{NiO} 0.03(02)$ & 99.73 \\
\hline \multicolumn{14}{|c|}{ Sample 111-504B-169R-1 (Piece 1) } \\
\hline $16 \mathrm{~B} \mathrm{gl}$ & 3 & $51.06(27)$ & $1.08(03)$ & $14.73(07)$ & $8.93(15)$ & $0.18(04)$ & $8.83(04)$ & $13.27(18)$ & $1.75(05)$ & $0.01(01)$ & & & 99.84 \\
\hline $\mathrm{pl}$ & 8 & 48.10 & $0.02(01)$ & $31.84(31)$ & $0.64(09)$ & $0.01(02)$ & $0.37(04)$ & $16.53(22)$ & $2.18(05)$ & $0.02(01)$ & & & 99.71 \\
\hline $34 \mathrm{~B} \mathrm{gl}$ & 4 & $50.43(35)$ & $1.18(04)$ & $13.92(36)$ & $9.38(18)$ & $0.18(03)$ & $9.33(28)$ & $13.28(22)$ & $1.75(04)$ & $0.02(01)$ & & & 99.47 \\
\hline $\mathrm{pl}$ & 3 & $49.27(05)$ & $0.01(01)$ & 31.37 (26) & $0.58(01)$ & $0.03(00)$ & $0.41(01)$ & $15.86(08)$ & $2.58(06)$ & $0.02(01)$ & & & 100.13 \\
\hline $35 \mathrm{~B} \mathrm{gl}$ & 3 & $50.50(16)$ & $1.07(04)$ & $15.16(10)$ & $8.30(23)$ & $0.15(02)$ & $8.62(06)$ & $13.43(08)$ & $1.62(07)$ & $0.02(01)$ & & & 98.87 \\
\hline & 3 & $48.62(30)$ & $0.04(01)$ & $32.15(29)$ & $0.39(04)$ & $0.02(00)$ & $0.38(04)$ & $16.41(09)$ & $2.28(07)$ & $0.02(01)$ & & & 100.31 \\
\hline $47 \mathrm{~B} \mathrm{gl}$ & 8 & $50.01(27)$ & $1.01(07)$ & $14.78(40)$ & $8.66(27)$ & $0.12(03)$ & $8.58(21)$ & $13.31(06)$ & $1.81(07)$ & $0.01(01)$ & & & 98.29 \\
\hline $\mathrm{pl}$ & 6 & $48.42(22)$ & $0.02(01)$ & 31.57 (26) & $0.54(06)$ & $0.00(00)$ & $0.39(03)$ & 16.23 (17) & $2.37(10)$ & $0.00(00)$ & & & 99.54 \\
\hline $50 \mathrm{~B} \mathrm{gl}$ & 5 & $50.56(11)$ & $1.19(03)$ & $13.21(07)$ & $9.35(18)$ & $0.13(01)$ & $9.25(12)$ & $13.08(16)$ & $1.72(03)$ & $0.01(01)$ & $0.09(04)$ & & 98.59 \\
\hline $\mathrm{pl}$ & 7 & 49.04 (57) & $0.02(01)$ & $29.64(40)$ & 2.86 (11) & $0.00(00)$ & $0.45(02)$ & $15.90(30)$ & $2.50(10)$ & $0.00(00)$ & $0.02(02)$ & & 100.43 \\
\hline $\mathrm{mt}$ & 4 & $0.20(07)$ & $0.53(03)$ & 8.10 (11) & $64.75(43)$ & $0.36(02)$ & $16.82(17)$ & $0.07(03)$ & $0.00(01)$ & $\mathrm{Cr}_{2} \mathrm{O}_{3} 2.56(16)$ & & $\mathrm{NiO} 0.41(02)$ & 93.80 \\
\hline $51 \mathrm{~B} \mathrm{gl}$ & 5 & $50.76(15)$ & $1.13(03)$ & $13.70(16)$ & $9.52(13)$ & $0.13(02)$ & $9.15(09)$ & $13.13(05)$ & $1.75(06)$ & $0.00(00)$ & $0.10(01)$ & & 99.37 \\
\hline $\mathrm{pl}$ & 6 & $49.38(43)$ & $0.02(01)$ & $30.23(28)$ & $2.09(08)$ & $0.00(00)$ & $0.41(02)$ & 16.00 (17) & $2.50(10)$ & $0.00(00)$ & $0.04(00)$ & & 100.67 \\
\hline $52 \mathrm{~B} \mathrm{gl}$ & 5 & 50.95 & $1.04(07)$ & $14.10(29)$ & $9.27(07)$ & $0.11(02)$ & $9.08(22)$ & $13.05(10)$ & $1.78(07)$ & $0.00(00)$ & $0.12(06)$ & & 99.50 \\
\hline $\mathrm{pl}$ & 6 & $49.51(38)$ & $0.01(01)$ & $30.80(85)$ & $1.41(28)$ & $0.00(00)$ & $0.40(04)$ & $15.96(33)$ & $2.51(13)$ & $0.00(00)$ & $0.03(02)$ & & 100.63 \\
\hline $79 \mathrm{~B} \mathrm{gl}$ & 5 & $52.44(29)$ & $1.13(03)$ & $14.44(20)$ & $7.35(21)$ & $0.14(01)$ & $9.41(22)$ & $13.38(20)$ & $0.91(02)$ & $0.01(00)$ & $0.06(03)$ & & 99.27 \\
\hline $\mathrm{pl}$ & 6 & 48.33 (39) & $0.01(01)$ & $32.32(26)$ & $0.21(04)$ & $0.00(00)$ & $0.46(03)$ & $17.01(31)$ & 1.85 (15) & $0.00(00)$ & & & 100.19 \\
\hline
\end{tabular}

Note: $\mathrm{cp}=$ clinopyroxene; $\mathrm{gl}=$ glass; $\mathrm{mt}=$ magnetite; $\mathrm{ol}=$ olivine; $\mathrm{pl}=$ plagioclase. Numbers in parenthesis denote one standard deviation in terms of least units cited. 


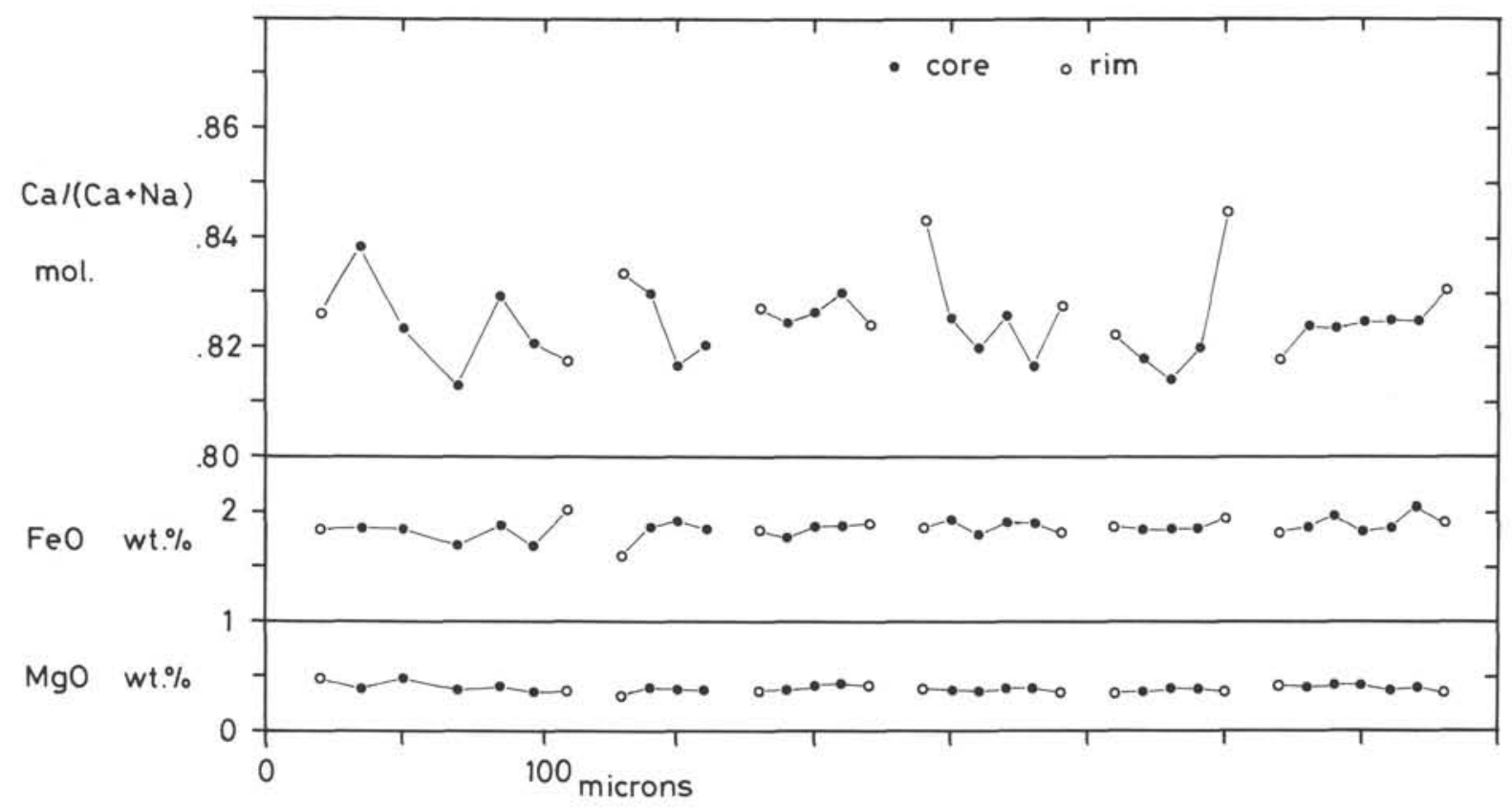

Figure 4. Compositional profiles of plagioclase in the product of run 26A (conditions given in Table 2). Some crystals show reverse zoning in terms of the $\mathrm{Ca} /(\mathrm{Ca}+\mathrm{Na})$ ratio. Only the rim composition was used to calculate the partition coefficients. 


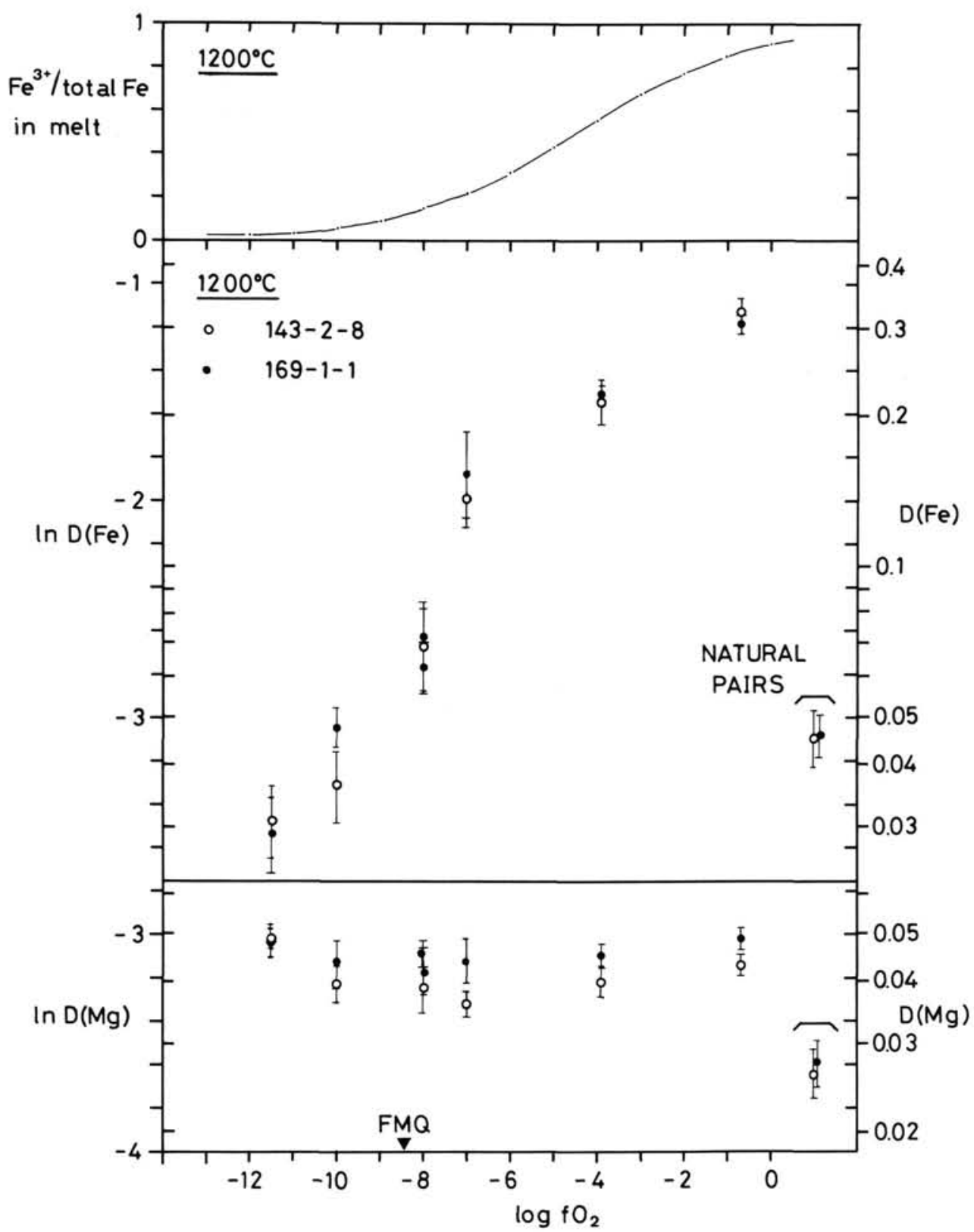

Figure 5. Variations in the $\mathrm{Fe}^{3+} /($ total Fe) ratio of the liquid from Sample 111-504B-143R-2 (Piece 8). The composition was calculated with the equation of Kilinc et al. (1983). The lower portion of the figure shows the natural logarithm of distribution coefficients of $\mathrm{FeO}^{*}$ and $\mathrm{MgO}$ between plagioclase and liquid against the variation of the natural logarithm of $\mathrm{f}_{2} . \mathrm{D}(\mathrm{Mg})$ is independent on $\mathrm{f}_{\mathrm{O}_{2}}$ while $\mathrm{D}(\mathrm{Fe})$ illustrates marked dependence upon the variation of $\log \mathrm{f}_{\mathrm{O}_{2}}$. FMQ $=$ fayalite-magnetite-quartz assemblage. 


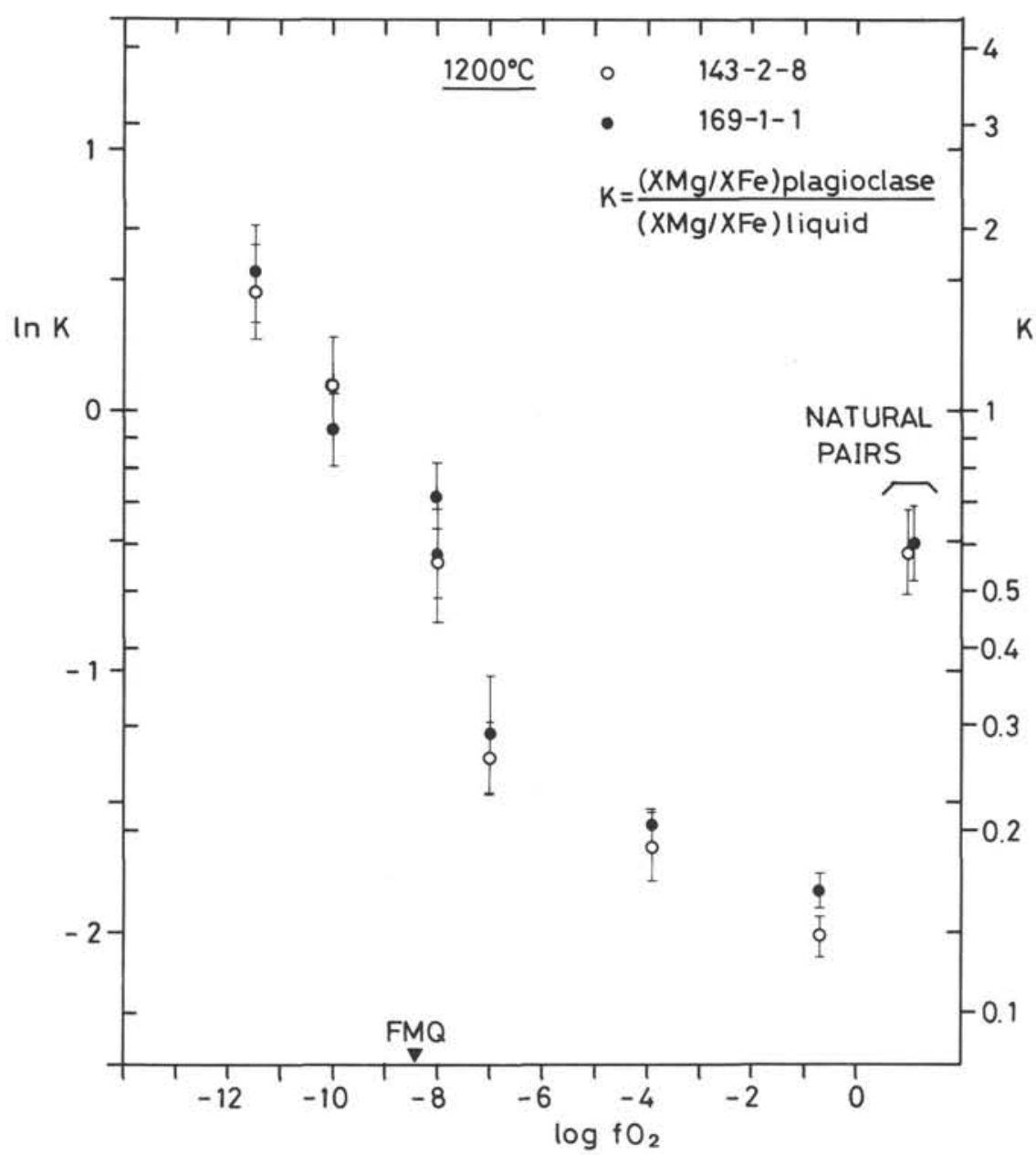

Figure 6. Natural logarithm of the exchange partition coefficient of $\mathrm{Mg}$ and Fe between plagioclase and magmas vs. the logarithm of $\mathrm{f}_{2}$ obtained in this work. The partition coefficients calculated from the phenocryst core and bulk-rock composition (shown on the right side of the figure) indicate the redox state of iron in the Leg 111 basalt samples is near that defined by fayalite-magnetite-quartz (FMQ) assemblage. 